\title{
CORPORATE GOVERNANCE DAN KINERJA KEUANGAN PERUSAHAAN (Studi pada Perusahaan Indonesia di Indeks LQ45 Tahun 2010-2014)
}

\author{
Halim Dedy Perdana* \\ Rizzky Pradana Putra \\ Sri Murni \\ Program Studi Akuntansi Fakultas Ekonomi dan Bisnis \\ Universitas Sebelas Maret \\ *perdana.hlm@gmail.com
}

\begin{abstract}
Purpose - The purpose of this study was to examine the effect of corporate governance on the financial performance of the company. Corporate governance is measured using a proxy board size, independent board, and managerial ownership. While the company's financial performance is measured using the Return On Equity (ROE).

Design / methodology / approach - The samples are companies included in the index LQ45 in 2010-2014 that have met the study criteria. The sample is determined by purposive sampling method with a total sample of 21 companies. This study uses multiple linear analyses to analyze influence of independent variables on the dependent variable.

Findings - The results of this study indicate that the independent board has a positive influence on the financial performance of the company, while managerial ownership has a negative effect on the financial performance of the company. On the other hand, this study did not find any influence of board size on the financial performance of the company.

Originality / value - This study examines whether the company's financial performance can be explained by determinants the same as those used in other similar studies. The results of the study indicate only independent board has positive effects on the company's financial performance.
\end{abstract}

Keywords: corporate governance, ROE, financial firm performance

\section{PENDAHULUAN}

Pada tahun 2008 perekonomian dunia sempat diguncangkan dengan terjadinya krisis ekonomi yang hampir melanda seluruh belahan dunia (Martsila dan Meiranto, 2013). Lemahnya Corporate governance dianggap berperan penting atas kebangkrutan yang menimpa sejumlah perusahaan besar dan krisis yang terjadi di berbagai negara baru-baru ini (Reddy, Locke, dan Scrimgeour, 2010; Ujunwa, 2012; Ross dan Crossan, 2012).

Di Indonesia, isu mengenai corporate governance telah mengemuka sejak Indonesia mengalami masa krisis berkepanjangan pada tahun 1998 (Hardikasari, 2011). Kemudian ditambah dengan terkuaknya skandal keuangan pada tahun 2001 yang terjadi di perusahaan publik yang melibatkan manipulasi laporan keuangan oleh PT. Lippo dan salah satu BUMN, PT. Kimia Farma, membuat isu mengenai corporate governance di Indonesia semakin meningkat pesat (Sekaredi, 2011). Terjadinya berbagai kasus penyajian laporan keuangan yang tidak semestinya ini menunjukkan terjadinya skandal keuangan yang merupakan bagian dari kegagalan laporan keuangan di dalam memenuhi kebutuhan informasi para pengguna laporan keuangan (Khafid, 2012).

Forum for Coporate Governance in Indonesia (2008) dalam penelitian Irawan dan Farahita (2008) menyebutkan bahwa survei yang dilakukan PricewaterhouseCoopers (PwC) atas investor internasional tahun 2002 untuk membandingkan kerangka corporate 
governance di Indonesia dengan negara lain dalam satu wilayah menunjukkan bahwa Indonesia pada tahun 2002 menduduki posisi terbawah dalam hal audit dan kepatuhan, akuntabilitas terhadap pemegang saham, standar pengungkapan dan transparansi, serta peranan direksi.

Corporate governance merupakan tata kelola perusahaan yang menjelaskan hubungan antara berbagai pihak dalam perusahaan yang menentukan antara arah dan kinerja perusahaan (Monks dan Minow, 2001). Corporate governance memiliki 4 sumber utama pembentuknya, yaitu etika individu dan budaya organisasi, mekanisme pengendalian internal, mekanisme pengendalian pasar/eksternal, hukum dan regulasi yang berlaku (Rajput dan Bharti, 2015). Isu mengenai coporate governance sampai saat ini masih menjadi pembahasan yang menarik untuk diperbincangkan hampir di seluruh belahan dunia. Hal ini dikarenakan, isu yang berkaitan dengan corporate governance telah dipandang penting guna mengatasi permasalahan finansial suatu perusahaan (Rajput dan Bharti, 2015).

Penerapan coprorate governance erat kaitannya dengan pengambilan keputusan investasi pemegang saham dan investor, dengan adanya penerapan corporate governance dalam perusahaan, pemegang saham dan investor akan lebih percaya terhadap pengelolaan perusahaan dan berkeyakinan akan memperoleh return atas investasi yang mereka lakukan karena penerapan corporate governance dapat melindungi kepentingan pemegang saham dan investor secara efektif (Hardikasari, 2011). Ghabayen (2012) juga menyatakan bahwa coporate governance akan melindungi kepentingan pemegang saham dan meningkatkan kinerja perusahaan. Oleh karena itu suatu perusahaan perlu melakukan penilaian kinerja, karena mampu menggambarkan aktivitas perusahaan, pangsa pasar, dan tingkat profitabilitas (Zehir, Altindag, dan Acar, 2011).

Tujuan dari penilaian kinerja adalah untuk memotivasi karyawan dalam mencapai sasaran organisasi dan dalam mematuhi standar perilaku yang telah ditetapkan sebelumnya agar membuahkan tindakan dan hasil yang diinginkan (Mulyadi, 2007). Penilaian kinerja perusahaan dikelompokkan menjadi dua, yaitu penilaian kinerja non-keuangan dan penilaian kinerja keuangan (Morse dan Davis, 1996).

Kinerja non-keuangan dapat dilihat dari kualitas pelayanan, kedisiplinan, kepuasan pelanggan, dan sebagainya, sedangkan kinerja keuangan biasanya diukur berdasarkan anggaran yang telah dibuat, yaitu dengan menganalisis selisih atau perbedaan antara kinerja aktual dengan anggaran yang telah disusun sebelumnya (Mulyadi, 2001).

Penilaian kinerja dengan menggunakan ukuran keuangan lebih sering digunakan karena terdapat standar perbandingan yang potensial, baik berupa laporan keuangan dimasa lalu atau dengan laporan keuangan perusahaan lain yang sejenis (Hansen dan Mowen, 1997). Kinerja keuangan dapat diukur dengan rasio profitabilitas dan rasio pasar (Puspitasari dan Ernawati, 2010). Menurut Bringham dan Houston (2010), ROE merupakan rasio yang paling penting atas pengambilan ekuitas perusahaan, pemegang saham pasti menginginkan tingkat pengembalian yang tinggi atas modal yang mereka investasikan, dan rasio yang ditunjukkan oleh ROE menunjukkan tingkat pengembalian yang akan mereka peroleh.

Penelitian ini menggunakan perspektif hubungan keagenan untuk dijadikan dasar dalam memahami corporate governance (Darmawati, Khomsiyah dan Rahayu, 2004). Teori keagenan (agency theory) dikemukakan Jensen dan Meckling pada tahun 1976. Teori keagenan (agency theory) menyatakan bahwa hubungan agensi muncul ketika satu orang atau lebih (principal) mempekerjakan orang lain (agent) untuk memberikan suatu jasa dan kemudian mendelegasikan wewenang pengambilan keputusan kepada agent tersebut (Jensen dan Meckling, 1976). Dalam teori agensi, principal (pemegang saham) sebagai pihak yang memiliki saham sepenuhnya meminta agent (manajemen) untuk memaksimalkan return bagi mereka (Berle dan Means, 1932; Pratt dan Zeckhauser, 1985 dalam Wulandari, 2006). Masalah keagenan muncul 
ketika tujuan dari principal dan agent bertentengan (Eisenhardt, 1989).

Menurut Hart (1995) dalam Gunarsih (2003) diperlukan penerapan corporate governance untuk mengurangi permasalahan keagenan antara pemegang saham dengan manajer, serta untuk menyamakan kepentingan antara pemegang saham (pemilik) dengan manajemen (pengelola). Menurut Jensen dan Meckling (1976) corporate governance perlu berperan sebagai monitoring dalam menyelesaikan masalah keagenan. Monitoring adalah mekanisme yang sengaja dibuat oleh pihak principal untuk mengawasi agent dengan membentuk dewan pengawas (dewan komisaris) serta melibatkan para pemegang saham dalam mengawasi jalannya perusahaan (Jensen dan Meckling, 1976).

Penelitian yang menguji pengaruh corporate governance terhadap kinerja keuangan perusahaan telah banyak dilakukan, seperti Abor dan Biekpe (2007) menemukan adanya hubungan yang positif antara corporate governance yang diproksikan menggunakan ukuran dewan, komposisi dewan, kemampuan dewan, kemampuan manajerial, dan CEO duality terhadap kinerja keuangan perusahaan yang diukur menggunakan ROA. Hasil lain ditemukan oleh Rajput dan Bharti (2015) yang meneliti 76 perusahaan yang terdaftar di BSE 100 dan menemukan hasil, corporate governance yang diproksikan menggunakan board size berpengaruh negatif terhadap kinerja keuangan perusahaan yang diukur menggunakan ROA, ROE, dan Tobin's Q.

Bervariasinya hasil penelitian sebelumnya dikarenakan perbedaan lokasi penelitian, proksi yang dipakai dan alat-alat ekonometrik yang digunakan (Ujunwa, 2012). Penelitian ini menggunakan proksi ukuran dewan komisaris, dewan komisaris independen, dan kepemilikan manajerial. Ukuran dewan komisaris berhubungan jumlah orang yang menjadi anggota dari dewan komisaris (Martsila dan Meiranto, 2013).

Dewan komisaris independen berhubungan dengan proporsi anggota dewan komisaris yang tidak berafiliasi dengan direksi,

anggota dewan komisaris lainnya dan pemegang saham pengendali, serta bebas dari hubungan bisnis atau hubungan lainnya yang dapat mempengaruhi kemampuannya untuk bertindak independen atau bertindak semata-mata demi perusahaan (KNKG, 2009). Kepemilikan manajerial merupakan mekanisme internal yang dianggap mampu menyelaraskan kepentingan pengelola dengan kepentingan para pemegang saham (Isshaq, Bokpin, dan Onumah, 2009).

Tujuan penelitian ini adalah untuk menemukan bukti empiris dan menguji apakah corporate governance yang diproksikan dengan ukuran dewan komisaris, dewan komisaris independen, dan kepemilikian manajerial berpengaruh terhadap kinerja keuangan perusahaan yang diukur dengan indikator ROE (Return on Equity) pada perusahaan di Indonesia. Struktur dari artikel ini adalah sebagai berikut, bagian 2 menyajikan penelitian terdahulu mengenai corporate governance, bagian 3 menyajikan hipotesis pengaruh antara corporate governance terhadap kinerja keuangan perusahaan. Metode penelitian yang digunakan tersaji pada bagian, dan hasil penelitian disajikan dalam bagian 5. Terkahir, bagian 6 menyajikan kesimpulan dari penelitian ini.

\section{Penelitian Terdahulu}

Wulandari (2006) menguji mekanisme corporate governance sebagai variabel independen terhadap kinerja perusaahaan publik di Indonesia sebagai variabel dependen. Corporate governance diproksikan menggunakan jumlah dewan direktur, proporsi dewan komisaris independen, debt to equity, dan kepemilikan institusional sebagai variabel independen, sedangkan Tobin's Q sebagai variabel dependen. Sampel pada penelitian ini adalah 91 perusahaan publik yang terdaftar di Bursa Efek Jakarta pada tahun 2000-2002. Hasil dari penelitian tersebut menunjukkan adanya pengaruh positif diantara kedua variabel.

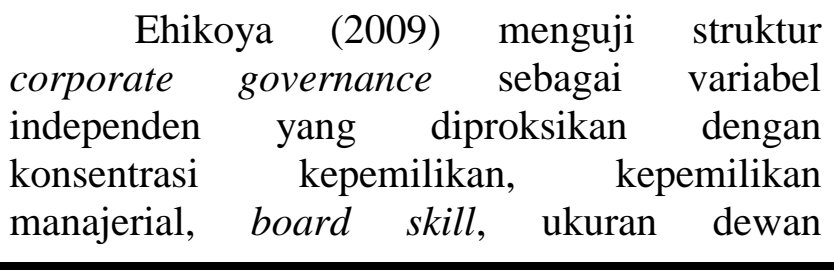


komisaris, dan dewan komisaris independen terhadap kinerja perusahaan sebagai variabel dependen yang diukur menggunakan ROA, ROE, PE, dan Tobin's Q. Sampel dalam penelitian ini adalah perusahaan yang terdaftar di Nigerian Stock Exchange sebanyak 107 perusahaan. Hasil dari penelitian ini menunjukkan adanya pengaruh positif dari konsetrasi kepemilikan dan ukuran dewan komisaris terhadap kinerja keuangan perusahaan yang diukur menggunakan ROA, ROE, dan PE, sedangkan kepemilikan manajerial dan dewan komisaris independen tidak berpengaruh terhadap kinerja keuangan perusahaan. Selain itu hanya dewan komisaris independen yang memiliki pengaruh terhadap kinerja keuangan perusahaan yang diukur menggunakan Tobin's Q.

Darwis (2009) menguji implementasi corporate governance seperti kepemilikan manajerial, kepemilikan institusional, dewan komisaris, dan komisaris independen sebagai variabel independen dan ROI sebagai variabel independen. Populasi dalam penelitian ini adalah perusahaan yang terdaftar di BEI pada tahun 2006-2008. Hasil dari penelitian ini menujukkan hanya implementasi corporate governance dan kepemilikan institusional yang berpangaruh terhadap ROI.

Reddy et al., (2010) menguji delapan variabel independen yaitu insider ownership, blockholders, proporsi dewan komisaris independen, ukuran dewan komisaris independen, debt, kebijakan dividen, komite audit, dan remuneration committee, serta satu variabel dependen yaitu kinerja keuangan perusahaan yang diukur menggunakan Tobin's $\mathrm{Q}$, ROA, dan market value to book value of assets. Sampel dalam penelitian ini adalah perusahaan yang terdaftar di NZX sebanyak 340 perusahaan. Hasil dari penelitian ini menunjukkan remuneration committee, blockholders, debt, dan kebijakan dividen berpengaruh positif terhadap kinerja keuangan perusahaan. Sedangkan insider ownership, komite audit, ukuran dewan komisaris, dan proporsi dewan komisaris tidak berpengaruh terhadap kinerja keuangan perusahaan.
Puspitasari dan Ernawati (2010) menguji pengaruh mekanisme corporate governance sebagai variabel independen yang diproksikan menggunakan kepemilikan manajerial, ukuran dewan komisaris, komisaris independen, dan konsetrasi kepemilikan terhadap kinerja keuangan sebagai variabel dependen yang diukur menggunakan rasio ROA, ROE, PER, dan Tobin's Q. Sampel dalam penelitian ini menggunakan 112 Badan Usaha yang terdaftar di BEI dan secara konsisten tepat waktu menyampaikan laporan keuangan periode 20072009. Hasil dari penelitian ini menunjukkan mekanisme corporate governance tidak memiliki pengaruh terhadap kinerja keuangan.

Mollah, Farooque, dan Karim (2012) menguji pengaruh corporate governance dan struktur kepemilikan terhadap kinerja perusahaan. Corporate governance diukur dengan ukuran dewan, komite audit, komite eksekutif sponsor director, sedangkan untuk struktur kepemilikan diukur dengan kepemilikan sponsor director, kepemilikan pemerintah, kepemilikan institusional, kepemilikan publik, dan kepemilikan asing. Variabel dependen, kinerja perushaan, diukur menggunakan ROA, ROE, Log of Market Capitalization, dan Tobin's Q. Penelitian menggunakan 19 perusahaan yang terdaftar di Pasar Saham Bostwana pada tahun 2000-2007 sebagai sampel. Hasil dari penelitian ini menunjukkan komite audit memiliki pengaruh positif terhadap kinerja perusahaan, sedangkan komite eksekutif dengan kepemilikan sponsor director memiliki pengaruh negatif terhadap kinerja perusahaan.

Wijayanti dan Mutmainah (2012) menguji pengaruh penerapan corporate governance terhadap kinerja keuangan perusahaan. Corporate governance sebagai variabel independen diproksikan oleh kepemilikan institusional, ukuran dewan direksi, aktivitas (rapat) dewan komisaris, proporsi komisaris independen, dan jumlah komite audit. Kinerja keuangan sebagai variabel dependen dalam penelitian ini diukur menggunakan cash flow return on asset (CFROA). Sampel yang digunakan adalah 57 perusahaan perbankan yang terdaftar di BEI. Penelitian ini 
menggunakan ukuran perusahaan sebagai variabel kontrol. Hasil penelitian ini menunjukkan bahwa kepemilikan institusional, ukuran dewan direksi, aktivitas (rapat) dewan komisaris, proporsi komisaris independen, dan jumlah komite audit tidak memiliki pengaruh dengan arah negatif terhadap kinerja keuangan perusahaan perbankan.

Martsila dan Meiranto (2013) menguji pengaruh corporate governance sebagai variabel independen yang diproksikan oleh independensi, ukuran dewan komisaris, kepemilikan manajerial, konsentrasi kepemilikan, dan leverage terhadap kinerja keuangan perusahaan sebagai variabel dependen yang diukur menggunakan ROA, ROE, PER, dan Tobin's Q. Sampel yang digunakan dalam penelitian ini adalah 123 perusahaan nonfinansial yang terdaftar di BEI. Hasil peneltian ini menunjukkan ukuran dewan komisaris berpengaruh positif terhadap ROA, sedangkan terhadap PER berpengaruh negatif. Konsentrasi kepemilikan berpengaruh positif terhadap ROA maupun ROE dan berpengaruh negatif terhadap PER. Leverage berpengaruh negatif terhadap ROA, PER, dan Tobin's Q. Selain itu, penelitian ini menemukan pengaruh positif antara ukuran perusahaan dengan kinerja keuangan perusahaan.

Alabdullah et al., (2014) menguji mekanisme corporate governance sebagai variabel independen yang diproksikan menggunakan ukuran dewan komisaris, dewan komisaris independen, dan CEO duality terhadap kinerja keuangan perusahaan sebagai variabel dependen yang diukur menggunakan market share. Sampel dalam penelitian ini adalah 109 perusahaan non-finansial yang terdaftar di Amman Stock Exchange (ASE) pada tahun 2011. Hasil penelitian ini menujukkan mekanisme corporate governance berpengaruh positif terhadap kinerja keuangan perusahaan.

Rajput dan Bharti (2015) menguji corporate governance sebagai variabel independen yang diproksikan menggunakan ukuran dewan komisaris terhadap kinerja perusahaan sebagai variabel dependen yang diukur menggunakan ROA, ROE, dan Tobin's Q. Sampel dalam penelitian ini adalah 76 perusahaan yang termasuk dalam BSE 100 . Hasil dari penelitian ini menunjukkan bahwa ukuran dewan komisaris berpengaruh negatif terhadap kinerja perusahaan.

\section{Hipotesis Penelitian}

Beberapa penelitian telah dilakukan sebelumnya untuk menguji pengaruh corporate governance terhadap kinerja keuangan perusahaan. Namun, dari penelitian-penelitian yang telah dilakukan memberikan hasil yang tidak konsisten karena perbedaan lokasi penelitian, proksi yang dipakai dan alat-alat ekonometrik yang digunakan (Ujunwa, 2012). Hipotesis dari penelitian ini tersaji di bawah ini.

\section{Ukuran Dewan Komisaris}

Dewan komisaris merupakan inti dari corporate governance, serta memiliki tiga tugas, yaitu menjamin pelaksanaan strategi perusahaan, mengawasi manajemen dalam mengelola perusahaan, serta mewajibkan terlaksananya akuntabilitas (Rini dan Ghozali, 2012; Wijayanti dan Mutmainah, 2012). Berdasarkan teori agensi, ukuran perusahaan yang besar membutuhkan dewan komisaris yang lebih besar untuk mengendalikan dan mengawasi tindakan manajemen dibandingkan dengan perusahaan yang lebih kecil (Ghabayen, 2012).

Ukuran dewan komisaris merupakan jumlah yang dianggap proporsional untuk mewakili pemegang saham didalam perusahaan, dengan adanya jumlah tersebut dewan komisaris dapat melaksanakan tugasnya secara efektif dan menjalankan corporate governance dengan bertanggung jawab kepada pemegang saham (Puspitasari dan Ernawati, 2010). Menurut KNKG (2006), jumlah anggota dewan komisaris harus disesuaikan dengan kompleksitas perusahaan dengan tetap memperhatikan efektivitas dalam pengambilan keputusan yang nantinya akan berdampak pada kinerja perusahaan. Fungsi monitoring yang dilakukan oleh dewan komisaris dipengaruhi oleh jumlah atau ukuran dewan komisaris (Siallagan dan Machfoedz, 2006). 
Jumlah anggota dewan komisaris yang besar sangat berpengaruh terhadap efektifitas pengawasan yang dijalankannya (Ismail et al., 2012 dalam Mustaqomah, 2011). Raharja (2012) mengatakan bahwa semakin banyak anggota dewan komisaris maka pengawasan terhadap dewan direksi akan semakin baik, karena dewan direksi akan mendapat masukan dan opsi yang lebih banyak (Raharja, 2012). Abor dan Biekpe (2007) membuktikan bahwa ukuran dewan komisaris berpengaruh positif terhadap kinerja keuangan perusahaan.

Berdasarkan penjelasan diatas, maka hipotesis yang dikembangkan dalam penelitian ini adalah sebagai berikut:

H1: Ukuran dewan komisaris berpengaruh positif terhadap kinerja keuangan perusahaan.

\section{Dewan Komisaris Independen}

Dewan komisaris menggambarkan puncak dari sistem pengendalian perusahaan (Razshinta, 2015). Jensen dan Meckling (1976) menyebutkan bahwa komisaris independen dalam dewan komisaris dapat mengurangi konflik agensi karena komisaris independen memiliki pengendalian dan pengawasan yang lebih baik untuk kegiatan oportunis yang dilakukan manajemen (Ghabayen, 2012). Pendapat lain juga menyatakan bahwa dewan komisaris independen akan lebih aktif dalam melakukan pengawasan terhadap perusahaan karena kepentingan mereka tidak terganggu oleh ketergantungan pada perusahaan (Utami, 2014).

Dengan adanya dewan komisaris independen, maka kepentingan pemegang saham, baik mayoritas maupun minoritas tidak diabaikan, karena dewan komisaris independen lebih bersikap netral terhadap keputusan yang dibuat oleh pihak manajer (Puspitasari dan Ernawati, 2010). Khan dan Awan (2012) dalam hasil penelitiannya menyatakan bahwa dewan komisaris independen berhubungan positif dengan kinerja keuangan perusahaan.

Berdasarkan penjelasan diatas, maka hipotesis yang dikembangkan dalam penelitian ini adalah sebagai berikut.
H2: Dewan komisaris independen berpengaruh positif terhadap kinerja keuangan perusahaan.

\section{Kepemilikan Manajerial}

Kepemilikan manajerial merupakan mekanisme internal yang dianggap mampu menyelaraskan kepentingan pengelola dengan kepentingan para pemegang saham (Isshaq et al.,2009). Kepemilikan manajemen terhadap saham perusahaan dipandang dapat menyelaraskan potensi perbedaan kepentingan antara pemegang saham luar dengan manajemen (Jansen dan Meckling, 1976).

Jensen dan Meckling (1976) juga menyebutkan bahwa semakin besar kepemilikan saham oleh manajemen maka berkurang kecenderungan manajemen untuk mengoptimalkan penggunaan sumber daya sekaligus mengurangi biaya agensi akibat adanya perbedaan kepentingan. Hal ini dikarenakan, keterlibatan manajemen dalam perusahaan melalui kepemilikan manajerial akan membuat manajamen ikut merasa memiliki perusahaan, sehingga manajemen akan semakin berhati-hati dalam mengambil keputusan dan akan semakin meningkatkan kinerja keuangan perusahaan, mengingat segala keuntungan maupun konsekuensi yang terjadi akan berdampak pula kepada manajemen (Martsila dan Meiranto, 2013). Martsila dan Meiranto (2013) dalam penelitiannya menemukan bahwa kepemilikan manajerial berpengaruh positif terhadap kinerja keuangan perusahaan.

Berdasarkan penjelasan diatas, maka hipotesis yang dikembangkan dalam penelitian ini adalah sebagai berikut:

H3: Kepemilikan manajerial berpengaruh positif terhadap kinerja keuangan perusahaan.

\section{METODOLOGI PENELITIAN \\ Pemilihan Sampel}

Populasi dalam penelitian ini adalah perusahaan yang termasuk ke dalam indeks LQ45 karena perusahaan yang termasuk dalam indeks LQ45 memiliki tingkat likuiditas yang tinggi serta saham dari perusahaan tersebut aktif 
diperdagangkan, sehingga perusahaan dalam indeks LQ45 memiliki prospek yang cukup bagus (Wisayang, 2011).

Teknik pengambilan sampel pada penelitian ini menggunakan metode purposive sampling yaitu metode pemilihan sampel yang didasarkan pada beberapa kriteria tertentu (Sekaran, 2011). Sehingga sampel dari penelitian ini adalah perusahaan yang termasuk ke dalam indeks LQ45 yang telah memenuhi kriteria. Kriteria tersebut adalah, (1) perusahaan yang secara konsisten masuk ke dalam indeks LQ45 untuk periode 2010-2014; (2) perusahaan yang memperoleh laba selama periode 20102014; dan (3) menyajikan data dan informasi yang lengkap terkait variabel-variabel yang digunakan dalam penelitian.

Data yang digunakan dalam penelitian ini adalah data sekunder yang berupa laporan tahunan (annual report) perusahaan yang terdaftar di Bursa Efek Indonesia. Data sekunder merupakan sumber data penelitian yang diperoleh peneliti secara tidak langsung melalui media perantara (diperoleh dan dicatat oleh pihak lain) (Algifari, 2003). Laporan tahunan (annual report) tersebut diperoleh dari
Indonesian Capital Market Directory (ICMD), situs resmi Bursa Efek Indonesia (BEI) yaitu www.idx.co.id, dan situs dari masing-masing perusahaan sampel.

Metode pengumpulan data yang digunakan pada penelitian ini adalah metode dokumentasi, yaitu dengan cara mengumpulkan dan mempelajari data-data yang diperlukan, yang dalam penelitian ini menggunakan data sekunder atau laporan tahunan (annual report) dari masing-masing perusahaan sampel.

\section{HASIL DAN PEMBAHASAN}

Dalam penelitian ini, nilai $t$ menggunakan nilai signifikansi 5\%. Jika hasil signifikansi nilai $\mathrm{t}$ menunjukkan $\mathrm{p}$-value lebih kecil dari 0,05 maka hipotesis diterima, jika pvalue lebih besar dari 0,05 maka hipotesis ditolak. Signifikansi nilai $\mathrm{t}$ dilakukan mengetahui seberapa jauh masing-masing variabel independen berpengaruh terhadap variabel dependen (Ghozali, 2011). Signifikansi nilai t dilakukan untuk memeriksa lebih lanjut dari ketiga variabel independen dalam penelitian ini yang berpengaruh terhadap ROE. Hasil dari penelitian ini disajikan dalam tabel berikut ini

Coefficients $^{\mathrm{a}}$

\begin{tabular}{|c|c|c|c|c|c|c|}
\hline & \multirow[b]{2}{*}{ Model } & Unstandardize & Coefficients & \multirow{2}{*}{$\begin{array}{c}\begin{array}{c}\text { Standardized } \\
\text { Coefficients }\end{array} \\
\text { Beta }\end{array}$} & \multirow[b]{2}{*}{$\mathrm{t}$} & \multirow[b]{2}{*}{ Sig. } \\
\hline & & $B$ & Std. Error & & & \\
\hline \multirow[t]{4}{*}{1} & (Constant) & .101 & .052 & & 1.941 & .056 \\
\hline & bod & .001 & .005 & .022 & .214 & .831 \\
\hline & ined & .292 & .082 & .367 & 3.577 & .001 \\
\hline & mown & -.575 & .206 & -.294 & -2.788 & .007 \\
\hline
\end{tabular}

a. Dependent Variable: roe

$\begin{array}{ll}\text { Keterangan: } & \\ \text { BOD } & \text { : Ukuran Dewan Komisaris } \\ \text { INED } & \text { : Dewan Komisaris Independen } \\ \text { MOWN } & : \text { Kepemilikan Manajerial }\end{array}$

Berdasarkan tabel di atas, Variabel ukuran dewan komisaris tidak memiliki ukuran dewan komisaris (BOD) memiliki pvalue sebesar 0,831 atau lebih besar dari 0,05. Hal ini dapat disimpulkan bahwa variabel pengaruh terhadap ROE, karena tidak signifikan pada level $5 \%$. 
Variabel dewan komisaris independen (INED) memiliki p-value sebesar 0,001 atau lebih kecil dari 0,05. Hal ini dapat disimpulkan bahwa variabel dewan komisaris independen memiliki pengaruh positif terhadap ROE, karena signifikan pada level 5\%.

Variabel kepemilikan manajerial (MOWN) memiliki p-value sebesar 0,007 atau lebih kecil 0,05. Hal ini menunjukkan bahwa variabel kepemilikan manajerial berpengaruh terhadap ROE. Namun, variabel kepemilikan manajerial memiliki nilai koefisien -0,294. Maka dapat disimpulkan variabel kepemilikan manajerial memiliki pengaruh secara negatif terhadap ROE.

Hasil pengujian dengan menggunakan regresi linier berganda menunjukkan nilai Adjusted $R^{2}$ pada model summary sebesar 0,231. Hal ini berarti sebesar 23,1\% kinerja keuangan perusahaan dengan ukuran Ruturn on Equity (ROE) dapat dijelaskan oleh variabel ukuran dewan komisaris, dewan komisaris independen, dan kepemilikan manajerial. Sedangkan sisanya sebesar $76,9 \%$ dijelaskan oleh variabel lain yang tidak diteliti dalam penelitian ini.

Dari analisis diatas dapat ditarik kesimpulan bahwa $H 1$ untuk penelitian ini diterima, sedangkan untuk $H 2, H 3$ untuk penelitian ini ditolak.

\section{KESIMPULAN}

Penelitian ini bertujuan untuk menguji pengaruh antara corporate governance yang diproksikan menggunakan ukuran dewan komisaris, dewan komisaris independen, dan kepemilikan manajerial terhadap kinerja keuangan perusahaan yang di ukur menggunakan rasio profitabilitas, yaitu Return On Equity (ROE). Berdasarkan hasil pengujian regresi linier berganda yang telah dilakukan, maka diperoleh kesimpulan sebagai berikut, (1) ukuran dewan komisaris tidak memliki pengaruh terhadap kinerja keuangan perusahaan; (2) dewan komisaris independen memiliki pengaruh positif terhadap kinerja keuangan perusahaan; (3) kepemilikan manajerial memiliki pengaruh negatif terhadap kinerja keuangan perusahaan.

\section{DAFTAR PUSTAKA}

Abor, J. dan N. Biekpe. 2007. Corporate Governance, Ownership Structure and Performance of SMEs in Ghana: Implication for Financing Opportunities. Corporate Governance. 7 (3): 288-300.

Alabdullah, T. T. Y; S. Yahya; dan T. Ramayah. 2014. Corporate Governance Mechanisms and Jordanian Companies' Financial Performance. Asian Social Science. 10 (22).

Algifari. 2003. Statistika Indukatif untuk Ekonomi dan Bisnis. Edisi Kedua. Akademi Manajemen Perusahaan YKPN. Yogyakarta.

Bringham F. E. dan J. Houston. 2010. DasarDasar Manajemen Keuangan: Assetilas of Financial Management. Jakarta: Penerbit Salemba Empat.

Darmawati, D; Khomsiyah; dan R. G. Rahayu. 2004. Hubungan Corporate Governance dan Kinerja Perusahaan. Makalah SNA VII.

Darwis, H. 2009. Corporate Governance Terhadap Kinerja Perusahaan. Jurnal Keuangan Dan Perbankan. 13 (3): 418-430.

Ehikioya, B. I. 2009. Corporate Governance Structure and Firm Performance in Developing Economies: Evidence from Nigeria. Corporate Governance. 9 (3): 231-243.

Eisenhardt, K. M. 1989. Agency Theory: An Assessment and Review. The Academy of Management Review. 14 (1): 576-74.

Forum for Corporate Governance in Indonesia (FCGI). 2008. What is Corporate Governance. Jakarta.

Ghabayen, M. A. 2012. Board Characteristics and Firm Performance: Case of Saudi 
Arabia. International Journal of Accounting and Financial Reporting. 2 (2): 168-200.

Gunarsih, T. 2003. Riset Empiris dalam Corporate Governance. Seminar Sehari: Issues Application and Research in Corporate Governance dalam Rangka Launching Pusat Studi Corporate Governance FE UTY.

Ghozali, I. 2011. Aplikasi Analisis Multivariate Dengan Program IBM SPSS. Semarang: Badan Penerbit Universitas Diponegoro.

Hansen, R. D. dan M. M. Mowen. 1997. Management Accounting and Control. Ohio: International Thompson Publishing Co.

Hardikasari, E. 2011. Pengaruh Penerapan Corporate Governance terhadap Kinerja Keuangan Pada Industri Perbankan yang Terdaftar di Bursa Efek Indonesia (BEI) Tahun 20062008. Skripsi. Universitas Diponegoro, Semarang.

Isshaq, Z; G. A. Bokpin, J. M. Onumah. 2009. Corporate Governance, Ownership Structure, Cash Holdings, and Firm Value on The Ghana Stock Exchange. The Journal of Risk Finance. 10(5): $488-499$.

Jensen, M.C. dan W.H. Meckling. 1976. Theory of The Firm: Manajerial Behaviour, Agency Cost, and Ownership Structure. Journal of Financial and Economics. 3 (4): 305-360.

Khafid, M. 2012. Pengaruh Tata Kelola Perusahaan (Corporate Governance) dan Struktur Kepemilikan Terhadap Persistensi Laba. Jurnal Dinamika Akuntansi. 4 (2): 139-148.

Khan, A. dan S. H. Awan. 2012. Effect of Board Composition on Firm's Performance: A Case of Pakistani Listed Companies. Interdisciplinary Journal of Contemporary Research in Business. 3 (10): 853-863.
Komite Nasional Kebijakan Governance (KNKG). 2006. Pedoman Umum Good Corporate Governance Indonesia. Jakarta.

Martsila, I. S. dan W. Meiranto. 2013. Pengaruh Corporate Governance Terhadap Kinerja Keuangan Perusahaan. Diponegoro Journal of Accounting. 2 (4): 1-12.

Mollah, S; E. A. Farooque; dan W. Karim. 2012. Ownership Structure, Corporate Governance and Firm Performance: Evidence from An African Emerging Market. Studies in Economics and Finance. 29 (4): 211-234.

Monks, R.A.G. dan N. Minow. 2001. Corporate Governance. 2nd ed. Blackwell Publishing.

Morse, W. J. dan J. R. Davis. 1996. Management Accounting: A Strategic Approach. South-Western College Pub.

Mulyadi. 2001. Sistem Perencanaan dan Pengendalian Manajemen. Jakarta: Salemba Empat.

Mustaqomah, E. 2011. Pengaruh Penerapan Mekanisme Corporate Governance Terhadap Kualitas Laba dengan Moderasi Kompetensi Komisaris Independen. Tesis. Universitas Sebelas Maret, Surakarta.

Puspitasari, F. dan E. Ernawati. 2010. Pengaruh Mekanisme Corporate Governance Terhadap Kinerja Keuangan Badan Usaha. Jurnal Manajemen Teori dan Terapan. 3 (2).

Raharja, I. B. 2012. Pengaruh Good Corporate Governance dan Ukuran Perusahaan Terhadap Kinerja Perusahaan (Studi Empiris Pada Perusahaan yang Terdaftar di BEI 2010). Diponegoro Journal of Accounting.

Rajput, N. dan Bharti. 2015. Shareholder Types, Corporate Governance and Firm Performance: An Anecdote from Indian Corporate Sector. Asian 
Journal of Finance \& Accounting. 7 (1).

Razshinta, H. 2015. Pengaruh Mekanisme Corporate Governance Terhadap Kualitas Laba Pada Perusahaan Perbankan yang Terdaftar di BEI Tahun 2011-2013. Skripsi. Universitas Sebelas Maret, Surakarta.

Reddy, K; S. Locke; dan F. Scrimgeour. 2010. The Efficacy of Principle-based Corporate Governance Practices and Firm Financial Performance: An Empirical Investigation. International Journal of Managerial Finance. 6 (3): 190-219.

Rini, T. S. dan I. Ghozali. 2012. Pengaruh Pemegang Saham Institusi, Komisaris Independen dan Komite Audit Terhadap Tingkat Profitabilitas Perusahaan. Diponegoro Journal of Accounting. 1 (1): 1-12.

Ross, A. dan K. Crossan. 2012. A Review of The Influence of Corporate Governance on The Banking Crises in The United Kingdom and Germany. Corporate Governance. 12 (2): 215-225.

Sekaran, U. 2011. Research Methods for Business (Metodologi Penelitian untuk Bisnis). 4th ed. Jakarta: Salemba Empat.

Sekaredi, S. 2011. Pengaruh Corporate Governance Terhadap Kinerja Keuangan Perusahaan. Skripsi. Univeritas Diponegoro, Semarang.

Siallagan dan M. Machfoedz. 2006. Mekanisme Corporate Governance, Kualitas Laba dan Nilai Perusahaan. Makalah SNA IX.
Ujunwa, A. 2012. Board Characteristics and The Financial Performance of Nigerian Quoted Firms. Corporate Governance. 12 (5): 656 - 674.

Utami, G. 2014. Board Governance dan Kinerja Keuangan Pada Badan Usaha Milik Negara (Studi Terhadap Badan Usaha Milik Negara Pada Tahun 20102012). Skripsi. Universitas Sebelas Maret, Surakarta.

Wulandari, N. 2006. Pengaruh Indikator Mekanisme Corporate Governance Terhadap Kinerja Perusahaan Publik di Indonesia. Fokus Ekonomi. 1 (2): 120-135.

Wijayanti, S. dan S. Mutmainah. 2012. Pengaruh Penerapan Corporate Governance Terhadap Kinerja Keuangan Pada Perusahaan Perbankan yang Terdaftar di Bursa Efek Indonesia (BEI) tahun 20092011. Diponegoro of Journal Accounting. 1 (2): 1-15.

Wisayang, V. R. W. 2011. Analisis Pengaruh Bid-Ask, Spread Market Value, dan Varian Return Saham Terhadap Holding Period pada Saham LQ45 (Studi di BEI Periode Februari 2008 Januari 2009). Tesis. Program Pasca Sarjana Universitas Diponegoro, Semarang.

Zehir, C; E. Altindag; dan A. Z. Acar. 2011. The Effects of Relationship Orientation through Innovation Orientation on Firm Performance: An Empirical Study on Turkish FamilyOwned Firms. Procedia-Social and Behavioral Sciences. 24: 896-908. 